\title{
Effect of exposure time and smoking habit on arsenic levels in biological samples of metal workers in comparison with controls
}

\author{
Bayram Yüksel 1, *, Nilgün Şen 2, Vugar Ali Türksoy ${ }^{3}$, Engin Tutkun ${ }^{3}$, \\ Tülin Söylemezoğlu 4 \\ 1 Giresun University, Espiye Vocational School, Giresun, Turkey. \\ 2 Turkish National Police Academy, Institute of Forensic Sciences, Ankara, Turkey. \\ Bozok University, Faculty of Medicine, Department of Public Health, Yozgat, Turkey. \\ 4 Ankara University, Institute of Forensic Sciences, Department of Forensic Toxicology, Ankara, Turkey. \\ * Correspondence: bayramyuksel83@gmail.com; bayram.yuksel@giresun.edu.tr (B.Y.); ORCID No: 0000-0001-7686- \\ 8648.
}

Received: 7 August 2017 / Revised: 18 October 2017 / Accepted: 19 October 2017

\begin{abstract}
The main goal of this study was to investigate the effect of exposure time and smoking habit on arsenic levels in biological samples of workers occupationally exposed to metals in comparison with non-occupational residents in Turkey. Blood, urine and hair samples were collected from 95 metal workers at Ankara Occupational Diseases Hospital, Turkey. Similarly, 94 hair samples were taken from controls. Arsenic levels in biological samples were measured using Graphite Furnace Atomic Absorption Spectrometry (GFAAS) equipped with Zeeman background correction and Hydride Generation Atomic Absorption Spectrometry (HGAAS). In metal workers; mean hair-arsenic levels of the smokers group $(2.05 \pm 1.97 \mathrm{mg} \mathrm{As} / \mathrm{kg})$ was found to be significantly higher than the mean of the hair-arsenic levels of non-smokers group $1.80 \pm 1.79 \mathrm{mg}$ As $/ \mathrm{kg}(\mathrm{p}<0.05)$. Mean hair-arsenic levels of exposure time group $(4-10$ years $)$ was found $(2.34 \pm 2.21 \mathrm{mg} \mathrm{As} / \mathrm{kg}$ ) to be significantly higher than the arithmetic mean of exposure time group (1-3 years) $(1.39 \pm 1.25 \mathrm{mg} \mathrm{As} / \mathrm{kg}, \mathrm{p}<0.01)$. As for the control group, mean of hair-arsenic levels in the smokers group $(0.133 \pm 0.012$ $\mathrm{mg} \mathrm{As} / \mathrm{kg}$ ) was found to be significantly higher than the mean of the hair-arsenic levels of non-smokers group $(0.101 \pm 0.006 \mathrm{mg} \mathrm{As} / \mathrm{kg}, \mathrm{p}<0.05)$. In addition, mean hair arsenic level in metal workers $(1.81 \pm 1.79 \mathrm{mg}$ As $/ \mathrm{kg})$ was found significantly higher than mean hair arsenic level in control group $(0.115 \pm 0.006 \mathrm{mg} \mathrm{As} / \mathrm{kg}, \mathrm{p}=0.00)$. Smoking increased the hair arsenic levels significantly both in metal workers and controls. The hair arsenic levels significantly enhanced with ascending exposure time. In addition, metal workers had significantly higher hair arsenic levels than controls. However, there was no significant effect detected in terms of urine and blood arsenic levels.
\end{abstract}

KEYWORDS: Arsenic; blood; hair; urine; smoking habit; occupational exposure.

\section{INTRODUCTION}

As a metalloid, arsenic is a prevalent environmental toxic substance [1] which has been classified as a human carcinogenic substance, group 1, by the International Agency for Research on Cancer [2]. Arsenic exposure in humans is mostly affiliated with the use of drinking water contaminated from natural and geological origins of inorganic arsenic [3,4]. Occupational exposure to arsenic has been expressed in varied works such as smelting of metallic ore and mining, use and fabricating of agricultural goods and wood preservatives, application of animal feed additives, manufacturing of electronic semiconductors and fabricating of glass and pigment products [5-8].

Arsenic can be found in inorganic and organic forms with different valence or oxidation states in the environment [3]. It exists in natural water mostly as inorganic arsenic compounds namely As(III) (arsenite) and $\mathrm{As}(\mathrm{V})$ (arsenate), respectively. As(III) compounds are more toxic than $\mathrm{As}(\mathrm{V})$ species $[9,10]$. Furthermore, organic arsenic species in the pentavalent oxidation state are much less toxic than inorganic arsenic compounds since metabolism of organic arsenicals is limited [11,12]. Trimethylarsine oxide (TMAO) and tetramethylarsonium (TETRA) are the examples of moderately toxic arsenic species, while arsenobetaine (AsB) and arsenocholine $(\mathrm{AsC})$ have no toxicity in mammals. From inorganic to organic forms, toxicity and mobility of As species in the body decreases in the manner $\mathrm{As}(\mathrm{iii})>\mathrm{As}(\mathrm{v})>$ organo-arsenic [13-16]. Some arsenic species [17] are listed in Figure 1.

How to cite this article: Yüksel B, Şen N, Türksoy VA, Tutkun E, Söylemezoğlu T. Effect of exposure time and smoking habit on arsenic levels in biological samples of metal workers in comparison with controls. Marmara Pharm J. 2018; 22(2): 218-226 


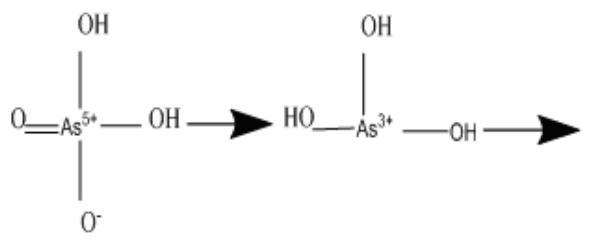

$$
\begin{array}{ll}
\text { Arsenate }\left(\mathrm{As}^{5+}\right) & \text { Arsenite }\left(\mathrm{As}^{3+}\right) \\
\left(\mathrm{LD}_{50} 112-175 \mathrm{mg} / \mathrm{kg}\right) & \left(\mathrm{LD}_{50} 15-44 \mathrm{mg} / \mathrm{kg}\right)
\end{array}
$$<smiles>C[As](C)(C)CC(=O)O</smiles>

Arsenobetaine $\left(\mathrm{LD}_{50} 10 \mathrm{~g} / \mathrm{kg}\right)$<smiles>C[N+](C)(C)CCO</smiles>

Arsenocholine $\left(\mathrm{LD}_{5_{0}} 6.5 \mathrm{~g} \mathrm{~kg}\right)$<smiles></smiles>

MMA DMA

$\left(\mathrm{LD}_{50} 960 \mathrm{mg} / \mathrm{kg}\right) \quad\left(\mathrm{LD}_{50} 650 \mathrm{mg} / \mathrm{kg}\right)$

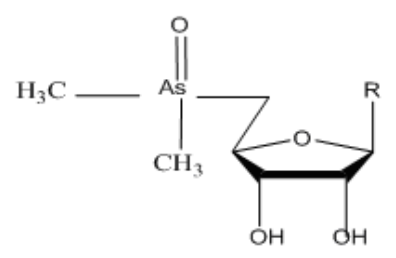

Arsenosugar (N/A)

Figure 1. Some important arsenic species: common inorganic arsenicals and their metabolites are listed in top row while organic arsenicals found in sea food are listed in bottom row [17].

Arsenic shows its toxic effects on numerous tissues by binding to sulfhydryl groups of proteins [18]. Acute and chronic exposure to arsenic is related with non-cancer health effects and diverse cancer forms including skin, bladder, liver and kidney $[19,20]$. Earlier studies revealed that individuals who excrete less arsenic could have higher risk in terms of developing arsenic-related diseases [21]. One of the primary mechanisms of arsenic-induced genomic vulnerability is known as DNA damage that is a character of cancer cells. Past studies show that arsenic can cause DNA damage in human cell lines acting as lymphocytes, TK6 cells and human lung fibroblast cell line [18]. Likewise, Shi et al. (2004) revealed that chronic arsenic exposure through calcium-mediated production of hydroxyl radicals, peroxynitrite and hypochlorous acid can cause a significant oxidative stress-induced DNA damage [22].

Inorganic arsenic exists environmentally in soil and various sorts of rock. Particularly, it occurs in minerals and ores containing copper, lead, cobalt, silver, and gold. Arsenic trioxide is volatilized throughout smelting and concentrates in flue dust that can involve up to $30 \%$ arsenic trioxide [6]. Occupational exposure to chemicals occurs most commonly via inhalation. Hence, arsenic exposure in metal workers takes place by inhalation of industrial soil and dust [23]. Arsenic cycle [24] in the nature is summarized in Figure 2.

Measurement of arsenic in biological samples can be operated by various methods such as neutron activation, X-ray fluorescence, atomic absorption and fluorescence spectrometry, and inductively coupled plasma atomic emission and mass spectrometry (ICP-AES and ICP-MS) [25]. In our previous studies, we have developed and validated methods for arsenic determination in human biological samples by Hydride Generation Atomic Absorption Spectrometry (HGAAS) [26] and Graphite Furnace Atomic Absorption Spectrometry (GFAAS) [3]. The objective of our present study was to investigate the effect of exposure time and smoking habit on arsenic levels in biological samples of metal workers in comparison with nonoccupational control group. Hence blood, urine and hair samples were taken from 95 metal workers at Ankara Occupational Diseases Hospital while 94 hair samples were taken from control group who have no known illness or exposure to interact arsenic levels in their biological samples.

\section{RESULTS AND DISCUSSION}

Arsenic is one of the most toxic elements. In humans, exposure to arsenic can occur via ingestion of foods and water or inhalation of dust contaminated with arsenic [27]. Total arsenic exposure is a sum of exposure to food, drinking water, soil and dust which are directly ingested, inhaled or penetrated in dermal route [28]. The lethal dose of arsenic for humans is approximately $125 \mathrm{mg}$ [29]. 


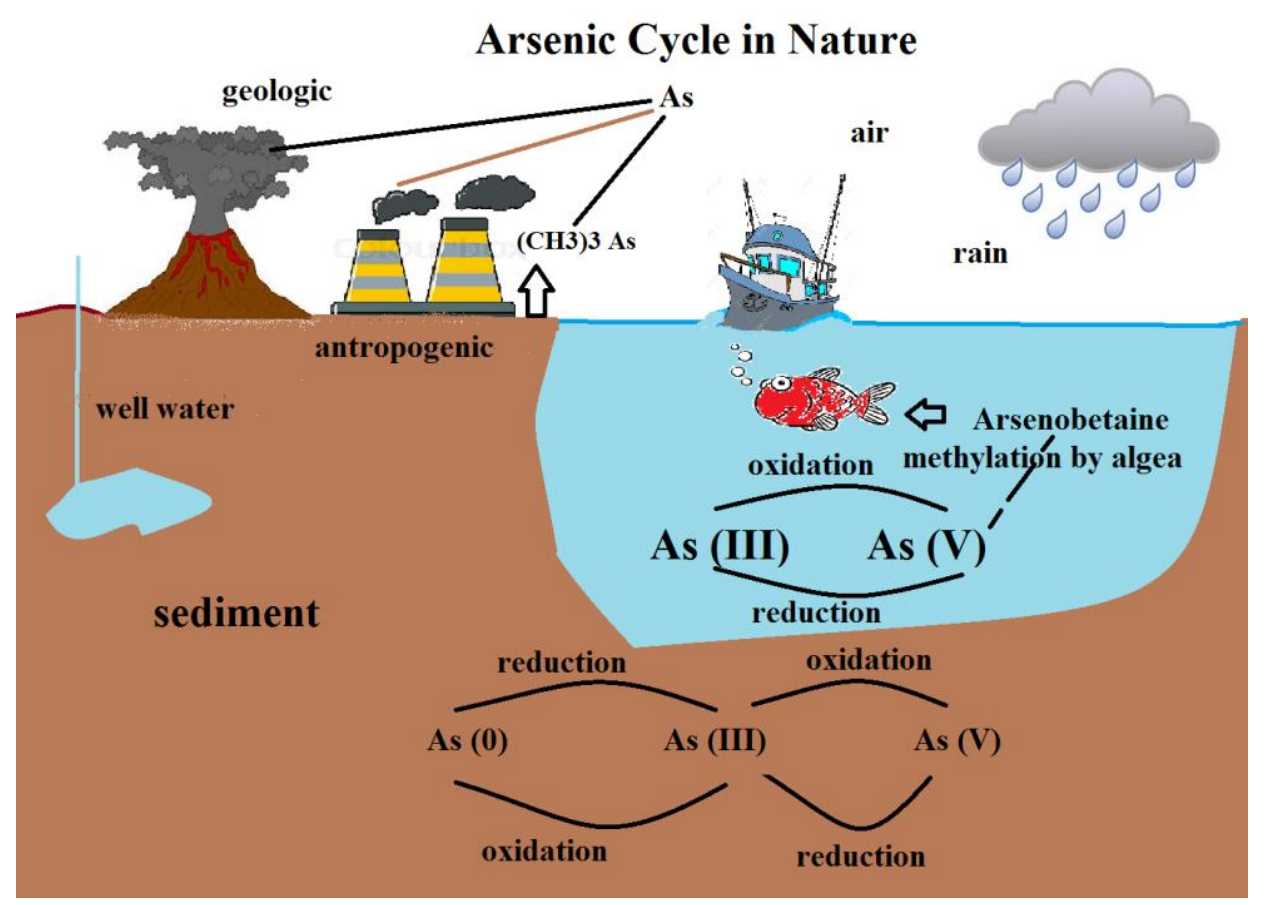

Figure 2. Arsenic cycle in the environment as a schematic diagram. This figure was redrawn with regard to the permission given on December 11, 2016 through simon@uic.edu by Prof. Dr. Simon Silver [24].

Metal mining and production, iron-steel manufacturing, medicine and cosmetics industry, use of herbicides and pesticides containing arsenic, consumption of coal, dyes, wood preserver with arsenic content are the examples of biogenic processes leading to arsenic contamination in the environment $[6,30,31]$. Industrial exposure to arsenic is particularly observed in developing countries such as Mexico, China and countries in Southeastern Asia. Furthermore, it was observed that people exposed to drink water contaminated with arsenic in Bangladesh were diagnosed with various cancer types especially skin cancer [32]. Occupational exposure occurs primarily via inhalation of dust or smoke contaminated with arsenic. However, in some cases, dermal or oral exposure to organic and inorganic arsenic compounds may also happen. Occupational exposure to arsenic generally takes place by inhalation of gases produced unintentionally when raw ores or metals with arsenic content are treated with acids [6].

For arsenic exposure, it is possible to achieve a more accurate estimation of total dose using biomarkers [33] particularly blood, urine and hair [3]. Urine can become a good choice in order to estimate the arsenic exposure because the main route of arsenic excretion occurs in kidneys [34]. Since inorganic arsenic is rapidly excreted from blood, arsenic levels in blood samples mainly reflect the current or comparatively high level of exposure [35]. Hair has a special potential to explain retrospective information due to arsenic exposure [36].

Mean hair arsenic levels of individuals who have no known exposure to arsenic ranged between 0.02 and $0.20 \mathrm{mg} \mathrm{As} / \mathrm{kg}[37,38]$. However, mean hair arsenic levels of subjects who were exposed to drinking water highly contaminated with arsenic ranged between 3.0 and $10.0 \mathrm{mg} \mathrm{As} / \mathrm{kg}$ [39]. Arsenic levels in human biological samples from various countries are listed in Table 1. Arsenic concentrations in blood, urine, nail, and hair of unexposed human adults are usually below $1 \mu \mathrm{g} / \mathrm{L}, 100 \mu \mathrm{g} / \mathrm{L}, 1 \mathrm{mg} / \mathrm{kg}$ and $1 \mathrm{mg} / \mathrm{kg}$, respectively [6] as listed in Table 2.

In this research, metal workers who have an obvious exposure to arsenic were selected as a target group to compare with the controls. Effect of exposure time and smoking habit on arsenic levels in biological samples of metal workers were interpreted. Moreover, creating a database due to occupational exposure to arsenic in Turkish population was also aimed.

In the risk group (metal workers); mean hair-arsenic levels of the smokers group $(2.05 \pm 1.97 \mathrm{mg} \mathrm{As} / \mathrm{kg})$ was found to be significantly higher than the mean of the hair-arsenic levels of non-smokers group $1.80 \pm 1.79$ $\mathrm{mg} \mathrm{As} / \mathrm{kg}(\mathrm{p}<0.05)$. On the contrary, no statistically significant difference was found between smokers and non-smokers groups of blood and urine samples. Statistical results due to effect of smoking habit on arsenic 
levels in blood, urine and hair samples of metal workers, are summarized in Table 3. As for the control group, mean of hair-arsenic level in the smokers group $(0.133 \pm 0.012 \mathrm{mg} \mathrm{As} / \mathrm{kg})$ was found significantly higher than the mean of the hair-arsenic level of non-smokers group $(0.101 \pm 0.006 \mathrm{mg} \mathrm{As} / \mathrm{kg}, \mathrm{p}<0.05)$. Arsenic is involved in tobacco naturally, and concentration of arsenic in tobacco plants are enhanced by treating them with insecticide containing lead arsenate. Therefore, smoking tobacco causes to arsenic exposure. Metal workers are under an elevated risk of developing lung cancer due to toxic metal exposure including arsenic. It is readily possible to state that metal workers who smoke are under higher risk [40, 41].

Mean hair-arsenic levels of exposure time group (4-10 years) was found $(2.34 \pm 2.21 \mathrm{mg} \mathrm{As} / \mathrm{kg}$ ) to be significantly higher than the arithmetic mean of exposure time group (1-3 years) $(1.39 \pm 1.25 \mathrm{mg} \mathrm{As} / \mathrm{kg}, \mathrm{p}<0.01)$. Statistical results due to effect of exposure time on arsenic levels in blood, urine and hair samples of metal workers, are listed in Table 4.

As can be seen in Table 5, mean hair arsenic level in risk group $(1.81 \pm 1.79 \mathrm{mg}$ As $/ \mathrm{kg})$ was found significantly higher than mean hair arsenic level in control group $(0.115 \pm 0.006 \mathrm{mg} \mathrm{As} / \mathrm{kg}, \mathrm{p}=0.00)$. This result demonstrated that metal workers were under risk of dangerous arsenic exposure. Mean hair arsenic levels $(1.81 \pm 1.79 \mathrm{mg} \mathrm{As} / \mathrm{kg})$ in metal workers were above the safe limits. Arsenic content in hair samples of unexposed humans are generally below $1 \mathrm{mg} / \mathrm{kg}$ [6). This knowledge is consisted with the mean arsenic levels in our control group $(0.115 \pm 0.006 \mathrm{mg} \mathrm{As} / \mathrm{kg})$.

According to another finding of the current study in terms of blood and urine arsenic content, there was no significant effect observed either in metal workers or controls. This situation can be expressed with the fact that arsenic can remain in the blood for 10 hours and in urine for 96 hours after exposure has finished [42].

Table 1. World-Wide reported arsenic levels in human biological samples.

\begin{tabular}{|c|c|c|c|c|}
\hline Country & $\begin{array}{l}\text { Biological } \\
\text { Sample }\end{array}$ & $\begin{array}{c}\text { Mean } \\
\text { Arsenic Level } \\
(\mu \mathrm{g} / \mathrm{g})\end{array}$ & Reference & $\begin{array}{c}\text { Reference } \\
\text { Number }\end{array}$ \\
\hline Catalonia, Spain & Lung & $<0.05$ & Garcia et al. (2001) & [43] \\
\hline Catalonia, Spain & Liver & $<0.05$ & Garcia et al. (2001) & [43] \\
\hline Catalonia, Spain & Kidney & $<0.05$ & Garcia et al. (2001) & [43] \\
\hline West Bengal & Nail & 7.32 & Mandal et al. (2003) & [44] \\
\hline West Bengal & Hair & 4.46 & Mandal et al. (2003) & [44] \\
\hline New York, USA & Urine & 15.7 & Tsuji et al. (2005) & [45] \\
\hline Fort Valley, Georgia & Urine & 11.6 & Hewitt et al. (1995) & [46] \\
\hline Fort Valley, Georgia & Hair & 0.78 & Hewitt et al. (1995) & [46] \\
\hline Fort Valley, Georgia & Nail & 0.79 & Hewitt et al. (1995) & [46] \\
\hline Glasgow, Scotland & Hair & 0.650 & Raie et al. (1996) & [47] \\
\hline Platine, Germany & Urine & 3.96 & Gebel et al. (1998) & [48] \\
\hline Platine, Germany & Hair & 0.028 & Gebel et al. (1998) & [48] \\
\hline Nurenberg, Germany & Lung & 5.5 & Kraus et al. (2000) & [49] \\
\hline Taiwan & Hair & 0.410 & Lin et al. (1997) & [50] \\
\hline Bombay, India & Hair & 0.475 & Dang et al. (1983) & [51] \\
\hline West Bengal, India & Hair & 0.550 & Srivastava et al. (2002) & [52] \\
\hline Iran & Hair & 0.073 & Raire (1996) & [47] \\
\hline Iceland & Hair & 0.040 & Raire (1996) & [47] \\
\hline Mongolia & Hair & 2.62 & Yang et al. (2002) & [53] \\
\hline Australia & Hair & 5.52 & Hinwood et al. (2003) & [54] \\
\hline China & Hair & 0.40 & Zhuang et al. (1989) & [55] \\
\hline China (Country-Wide) & Hair & 0.571 & Yang et al. (1996) & [56] \\
\hline China (Tongju) & Hair & 4.40 & Tang et al. (2001) & [57] \\
\hline China (Tongju) & Urine & 0.160 & Tang et al. (2001) & [57] \\
\hline China (Xinjiang) & Urine & 0.011 & Xu et al. (2009) & [58] \\
\hline China (Xinjiang) & Hair & 1.680 & Jin et al. (2003) & [59] \\
\hline China (Xinjiang) (Control) & Hair & 0.65 & Jin et al. (2003) & [59] \\
\hline Taiwan & Urine & 0.259 & Hsueh and Huang (1998) & {$[60]$} \\
\hline Pakistan & Hair & 1.06 & Afridi et al. (2011) & [61] \\
\hline Pakistan & Urine & 0.04 & Afridi et al. (2011) & [61] \\
\hline
\end{tabular}


Table 2. Normal Arsenic Levels in Human Biological Samples.

\begin{tabular}{cccc}
\hline Blood & Urine & Nail & Hair \\
\hline$<1 \mu \mathrm{g} / \mathrm{L}$ & $<100 \mu \mathrm{g} / \mathrm{L}$ & $\leq 1 \mathrm{mg} / \mathrm{kg}$ & $\leq 1 \mathrm{mg} / \mathrm{kg}$ \\
\hline
\end{tabular}

Table 3. Statistics due to the effect of smoking habit on arsenic levels in blood, urine and hair samples of metal workers.

\begin{tabular}{|c|c|c|c|c|c|c|c|}
\hline \multicolumn{2}{|c|}{ Smoking Habit } & (n) & Mean & SD & Minimum & Maximum Value & $p$ value \\
\hline Blood & No & 27 & 21.53 & 10.96 & 5.21 & 46.93 & \multirow{3}{*}{.891} \\
\hline \multirow{2}{*}{$\begin{array}{l}\text { Arsenic } \\
(\mu \mathrm{g} / \mathrm{L})\end{array}$} & Yes & 68 & 21.14 & 13.10 & 3.83 & 52.44 & \\
\hline & Total & 95 & 21.25 & 12.47 & 3.83 & 52.44 & \\
\hline \multirow{3}{*}{$\begin{array}{c}\text { Urinary } \\
\text { Arsenic } \\
(\mu \mathrm{g} / \mathrm{L})\end{array}$} & No & 27 & 5.66 & 4.10 & 1.26 & 17.83 & \multirow{3}{*}{.343} \\
\hline & Yes & 68 & 6.74 & 5.30 & 1.29 & 27.54 & \\
\hline & Total & 95 & 6.43 & 4.99 & 1.26 & 27.54 & \\
\hline \multirow{3}{*}{$\begin{array}{c}\text { Hair } \\
\text { Arsenic } \\
(\mathrm{mg} / \mathrm{kg})\end{array}$} & No & 27 & 1.16 & .97 & .15 & 3.91 & \multirow{3}{*}{$.025^{*}$} \\
\hline & Yes & 68 & 2.05 & 1.97 & .06 & 7.90 & \\
\hline & Total & 95 & 1.80 & 1.79 & .06 & 7.90 & \\
\hline
\end{tabular}

\section{CONCLUSION}

According to statistical analysis for blood and urine arsenic levels, there was no significant association found due to exposure time or smoking habit. However, smokers both in metal workers and controls have statistically higher hair-arsenic levels than non-smokers. Metal workers who were exposed to arsenic in ranging from 4 to 10 years had statistically higher hair-arsenic levels than workers who were exposured to arsenic ranging from 1 to 3 years $(p=0.01)$. Hence, it was observed that hair was relatively one of the best biomarkers to explain chronic long term arsenic exposure. It was found that mean hair arsenic level of metal workers were significantly higher than the controls $(p=0.00)$. Therefore, it was observed that hair arsenic levels increased significantly with ascending occupational exposure as well.

\section{MATERIALS AND METHODS}

\subsection{Instrumentation}

The analysis was carried out with a dual atomic absorption spectrophotometer (AAS) system (Varian240). Arsenic measurements in hair samples were performed using a Varian AA240 atomic absorption spectrometer (Varian, Victoria, Australia) equipped with a Varian VGA 77 vapor generation system, while blood and urinary arsenic levels were determined using a Varian AA240Z atomic absorption spectrometer (Varian, Victoria, Australia), equipped with a Zeeman background correction system. A boosted-discharge hollow cathode lamp (Agilent, Australia) was used as the excitation source for arsenic. The digestion procedure for the blood and hair samples was carried out using a Mars Xpress microwave system (CEM, Matthews, NC, USA) with PTFE microwave digestion vessels.

\subsection{Standard Solutions and Reagents}

A $1000-\mu \mathrm{g} / \mathrm{mL}$ arsenic stock solution was obtained from SCP Science (Courtaboeuf, France). Triton ${ }^{\circledR}$ X100, polyethylene glycol mono (p-1,1,3,3-tetramethylbutylphenyl) ether, was obtained from Scharlau (Barcelona, Spain). Nitric acid $\left(\mathrm{HNO}_{3}, 65 \%\right)$ was purchased from Merck (Darmstadt, Germany). Hydrochloric acid $(\mathrm{HCl}, 37 \%)$, sodium hydroxide $(\mathrm{NaOH})$, and hydrogen peroxide $\left(\mathrm{H}_{2} \mathrm{O}_{2}\right)$ were purchased from Merck (Darmstadt, Germany). Sodium borohydride $\left(\mathrm{NaBH}_{4}\right)$ was obtained from Fluka (Buchs, Switzerland) and potassium iodide (KI) from Sigma (St. Louis, MO, USA). All chemicals used were of analytical reagent grade unless otherwise specified. Ultrapure water (Human UP 900 Scholar-UV, Korea), with a resistivity of $18 \mathrm{M} \Omega$ $\mathrm{cm}$, was used to prepare the solutions for the experimental process. Argon gas with a purity of $99.999 \%$ was purchased from a local supplier (Vaşak Gaz, Ankara, Tukey). BCR-CRM 397 human hair powder (Community 
Bureau of Reference BCR, Institute for Reference Materials and Measurement, Belgium) and Seronorm ${ }^{\mathrm{TM}}$ Trace Elements Whole Blood L-2 (Sero AS, Billingstad, Norway) were used as the certified reference materials.

Table 4. Statistics due to effect of exposure time on arsenic levels in blood, urine and hair samples of metal workers.

\begin{tabular}{|c|c|c|c|c|c|c|c|}
\hline \multicolumn{2}{|c|}{$\begin{array}{c}\text { Exposure Time } \\
\text { (Year) }\end{array}$} & (n) & Mean & SD & $\begin{array}{l}\text { Minimum } \\
\text { Value }\end{array}$ & $\begin{array}{l}\text { Maximum } \\
\text { Value }\end{array}$ & $p$ value \\
\hline \multirow{3}{*}{$\begin{array}{l}\text { Blood } \\
\text { Arsenic } \\
(\mu g / L)\end{array}$} & $1-3$ & 54 & 21.49 & 12.91 & 4.40 & 52.44 & \multirow{3}{*}{0.835} \\
\hline & $4-10$ & 41 & 20.95 & 12.02 & 3.83 & 50.09 & \\
\hline & Total & 95 & 21.25 & 12.47 & 3.83 & 52.44 & \\
\hline \multirow{3}{*}{$\begin{array}{c}\text { Urinary } \\
\text { Arsenic } \\
(\mu \mathrm{g} / \mathrm{L})\end{array}$} & $1-3$ & 54 & 6.45 & 5.35 & 1.29 & 27.54 & \multirow{3}{*}{0.967} \\
\hline & $4-10$ & 41 & 6.41 & 4.54 & 1.26 & 19.94 & \\
\hline & Total & 95 & 6.43 & 4.99 & 1.26 & 27.54 & \\
\hline \multirow{3}{*}{$\begin{array}{c}\text { Hair } \\
\text { Arsenic } \\
(\mathrm{mg} / \mathrm{kg})\end{array}$} & $1-3$ & 54 & 1.39 & 1.25 & .06 & 4.69 & \multirow{3}{*}{$0.01^{* *}$} \\
\hline & $4-10$ & 41 & 2.34 & 2.21 & .19 & 7.90 & \\
\hline & Total & 95 & 1.80 & 1.79 & .06 & 7.90 & \\
\hline
\end{tabular}

Table 5. Statistics due to effect of occupational exposure on hair-arsenic levels in comparison with controls.

\begin{tabular}{|c|c|c|c|c|c|c|}
\hline & & $\mathrm{N}$ & $\begin{array}{c}\text { Mean As Concentration } \\
\pm \mathrm{SD}(\mathrm{mg} / \mathrm{kg})\end{array}$ & $\begin{array}{l}\text { Minimum Value } \\
(\mathrm{mg} / \mathrm{kg})\end{array}$ & $\begin{array}{l}\text { Maximum } \\
\text { Value } \\
(\mathrm{mg} / \mathrm{kg})\end{array}$ & P Value \\
\hline \multirow{2}{*}{ Occupation } & Metal Workers & 95 & $1.81 \pm 1.79$ & 0.06 & 7.90 & \multirow{2}{*}{$0.00^{*}$} \\
\hline & Control & 94 & $0.115 \pm 0.01$ & 0.021 & 0.312 & \\
\hline
\end{tabular}

\subsection{Study Subjects}

For the risk group (metal workers); blood, urine, and hair samples were collected from 95 metal workers (volunteers) at the Ankara Occupational Diseases Hospital, Turkey. The patients ranged in age from 18-61 years. Similarly, 94 hair samples were taken from controls ranged in age from 18-74 years, who have no known illness or exposure to interact arsenic levels in their hair samples. This study was ethically approved by the Research Ethics Committee of the Medical Faculty-Ankara University (Decision Number:11-34312/25.06.2012). Each volunteer was given a written informed consent form in accordance with the principles as established in The Declaration of Helsinki (World Medical Association, Declaration of Helsinki, 1964). The blood, urine, and hair samples were stored separately at $4{ }^{\circ} \mathrm{C}$ in vacationer blood collection tubes, polypropylene tubes, and polyethylene lock bags, respectively, until the day of analysis.

In this study, we followed the procedures that we previously published in our earlier studies [3, 26]. In order to prepare calibration standards at the concentrations of 3.0, 6.0, 9.0, 12.0, and $15.0 \mu \mathrm{g} / \mathrm{L}$, a $1000-\mu \mathrm{g} / \mathrm{mL}$ arsenic stock solution was diluted in $5 \%$ (v:v) $\mathrm{HNO}_{3}$ for GFAAS analysis of blood and urine samples. All glassware was kept in $10 \%$ (v:v) nitric acid for at least one night prior to each experimental work. Prior to analysis, the biological samples (except for urine) were pre-treated using the acid digestion procedure. One milliliter of each blood sample was taken into Teflon ${ }^{\circledR}$ tubes. The microwave system (CEM Mars Xpress) was operated for digestion of the samples with $5 \mathrm{~mL}$ of $65 \% \mathrm{HNO}_{3}$ solution. For the urine samples, 1 -mL amounts were mixed with $5 \mathrm{~mL}$ of $65 \% \mathrm{HNO}_{3}$ [3].

\subsection{Procedure}

In order to prepare calibration standards at the concentrations of 1.0, 2.0, 3.0, 4.0, and 5.0 $\mu \mathrm{g} / \mathrm{L}$, a 1000$\mathrm{\mu g} / \mathrm{mL}$ arsenic stock solution was diluted in $20 \%$ (v:v) $\mathrm{HCl}$ and $1 \%(\mathrm{w}: \mathrm{v})$ KI for HGAAS analysis of hair samples. A $0.6 \%$ (w:v) $\mathrm{NaBH}_{4}$ solution containing $0.5 \%$ (w:v) $\mathrm{NaOH}$ was used as a reductant where $5 \mathrm{M}$ of $\mathrm{HCl}$ was used as an acidifier in the hydride generation module. $100 \mathrm{mg}$ amounts of hair samples were taken and washed with Triton- $X$, rinsed, and left standing to air dry. The same microwave digestion procedure was also applied to the hair samples [25]. All biological samples were diluted with ultra-pure water to $10 \mathrm{ml}$. The 
GFAAS and HGAAS methods were tested by studying the certified reference materials of Seronorm ${ }^{\mathrm{TM}}$ Trace Elements Whole Blood Level-2 and human hair powder (CRM 397).

\subsection{Statistical Analysis}

Statistical analysis was performed using The Statistical Package for Social Sciences (SPSS) version 19.0 software for Windows. All results were expressed as mean \pm standard deviation (SD) of the mean. Normality of data distribution was evaluated with Kolmogorov-Smirnov test. Statistical significances between mean values were assessed using Student-t test while mean values of exposure time groups were evaluated using chi-square test. The statistical significance was considered as $\mathrm{p}<0.05$.

Acknowledgements: This work was partially published as an abstract poster presentation at the $51^{\text {th }}$ Congress of the European Societies of Toxicology in Porto, Portugal, Toxicology Letters 238 [2] S367, 2015, and financially supported by Turkish Prime Ministry State Planning Organization Research Fund, Grant Number: 2003K1201902.

Author contributions: Concept - B.Y., T.S.; Design - B.Y., T.S., E.T.; Supervision - T.S.; Materials - E.T; Data Collection and/or Processing - B.Y., V.T.; Analysis and/or Interpretation - B.Y., N.Ş., V.T., T.S.; Literature Search - B.Y., N.Ş., T.S.; Writing - B.Y.; Critical Reviews - B.Y.; N.Ş.; V.T., E.T.,T.S

Conflict of interest statement: The authors declared no conflict of interest in the manuscript.

\section{REFERENCES}

[1] Vahter M. Methylation of inorganic arsenic in different mammalian species and population groups. Sci Prog. 1999;82:69-88.

[2] IARC (International Agency for Research on Cancer): Some drinking-water disinfectants and contaminants, including arsenic, IARC Monographs on the evaluation of carcinogenic risks to humans, 84 (2004).

[3] Yüksel B, Kayaalti Z, Söylemezoğlu T, Türksoy VA, Tutkun E. GFAAS determination of arsenic levels in biological samples of workers occupationally exposed to metals. At Spectrosc. 2015; 36(4): 171-176.

[4] Yüksel B, Eroğlu A, Kayaaltı Z, Söylemezoglu T. Arsenic toxicity and its analysis in biological samples. J For Med. 2015;29(3):179-186.

[5] EPA. Arsenic, inorganic (CASRN 7440-38-2): Carcinogenicity assessment for lifetime exposure. Washington, DC: Integrated Risk Information System (IRIS), U.S. Environmental Protection Agency, 1998.

[6] ATSDR. Toxicological profile for arsenic. Atlanta, GA: Agency for Toxic Substances and Disease Registry, U.S. Department of Health and Human Services, Public Health Service, 2007.

[7] WHO. Arsenic and arsenic compounds, 2nd edn. Geneva, Switzerland: Environmental Health Criteria 224, International Programme on Chemical Safety, World Health Organization, 2001.

[8] Surdu S, Fitzgerald EF, Bloom MS, et al. Occupational exposure to arsenic and risk of nonmelanoma skin cancer in a multinational European study. Int J Cancer. 2013; 133(9): 2182-2191.

[9] Çiftçi TD, Henden E. Arsenic Speciation of Waters from the Aegean Region, Turkey by Hydride Generation: Atomic Absorption Spectrometry. Bull Environ Contam Toxicol. 2016;97:272-278.

[10] Sharma VK, Sohn M. Aquatic arsenic: toxicity, speciation, transformations, and remediation. Environ Int. 2009;35:743-759.

[11] Cohen SM, Arnold LL, Eldan M, Lewis AS, Beck BD. Methylated arsenicals: the implications of metabolism and carcinogenicity studies in rodents to human risk assessment. Crit Rev Toxicol. 2006; 36:99-133.

[12] Hughes MF, Beck BD, Chen Y, Lewis AS, Thomas DJ. Arsenic exposure and toxicology: A historical perspective. Toxicol Sci. 2011;123(2):305-332.

[13] Cullen WR, Reimer KJ. Arsenic speciation in the environment. Chem Rev. 1989; 89:713-764.

[14] Gebel, TW. Genotoxicity of arsenical compounds. Int J Hyg Environ Health. 2001; 203: 249-262.

[15] Vahter M, Marafante E. In vivo methylation and detoxication of arsenic. The biological alkylation of heavy elements. Royal Soceity of Chemistry, London, UK. 1988; 66: 105-119. 
[16] Sattar A, Xie S, Hafeez MA, Wang X, Hussain HI, Iqbal Z, Pan Y, Iqbal M, Shabbir MA, Yuan Z. Metabolism and toxicity of arsenicals in mammals. Environ Toxicol Pharmacol. 2016; 48: 214-224.

[17] Liu J, Lu Y, Wu Q, Goyer RA, Waalkes MP. Mineral arsenicals in traditional medicines: orpiment, realgar, and arsenolite. J Pharmacol Exp Ther. 2008; 326(2): 363-368.

[18] Bhattacharjee P, Chatterjee D, Singh KK, Giri AK. Systems biology approaches to evaluate arsenic toxicity and carcinogenicity: An overview. Int J Hyg Environ Health. 2013; 216(5):574-86.

[19] Hayakawa T, Kobayashi Y, Cui X, Hirano S. A new metabolic pathway of arsenite: arsenic-glutathione complexes are substrates for human arsenic methyltransferase Cyt19. Arch Toxicol. 2005; 79(4): 183-191.

[20] Rosen BP, Liu Z. Transport pathways for arsenic and selenium: a minireview. Environ Int. 2009; 35(3): $512-515$.

[21] Porter KE, Basu A, Hubbard AE, Bates MN, Kalman D, Rey O, Smith A, Smith MT, Steinmaus C, Skibola CF. Association of genetic variation in cystathionine-beta-synthase and arsenic metabolism. Environ Res. 2010; 110: 580587.

[22] Shi H, Hudson LG, Ding W, Wang S, Cooper KL, Liu S, Chen Y, Shi X, Liu KJ. Arsenite causes DNA damage in keratinocytes via generation of hydroxyl radicals. Chem Res Toxicol. 2004; 17(7): 871-878.

[23] Yüksel B, Kayaalti Z, Türksoy VA, Tutkun E, Söylemezoglu T. Evaluation of arsenic levels in biological samples of smelter workers in Turkey. Toxicol Lett. 2013; 221S: 251.

[24] Mukhopadhyay R, Rosen BP, Phung LT, Silver S. Microbial arsenic: from geocycles to genes and enzymes. FEMS Microbiol Rev. 2002; 26(3):3 11-25.

[25] Hughes MF. Biomarkers of exposure: a case study with inorganic arsenic. Environ Health Perspect 2006; 114(11): 1790-1796.

[26] Yüksel B, Mergen G, Söylemezoglu T. Assessment of arsenic levels in human hair by hyride generation atomic absortion spectrometry: A toxicological application. At Spectrosc 2010; 31(1): 1-5.

[27] Saad A, Hassanien MA. Assessment of arsenic level in the hair of the nonoccupational Egyptian population: Pilot study. Environ Int 2001; 27: 471-478.

[28] Thornton I. Arsenic in the global environment: looking towards the millennium. In: Chappell WR, Abernathy CO, Calderon RL, editors. Arsenic exposure and health effects. 1st ed. Oxford, UK: Elsevier 1999.

[29] Bates MN, Smith AH, Hopenhayn-Rich C. Arsenic toxicity. Am J Epidemiol 1994;135: 462-76.

[30] Nriagu JO, Pacyna JM. Quantitative assessment of worldwide contamination of air, water and soils by trace elements. Nature 1988; 333:134- 9.

[31] Abernathy CO, Liu Y, Longfellow D, Aposhian HV, Beck B, Fowler B, Goyer R, Menzer R, Rossman T, Thompson C, Waalkes M. Arsenic: health effects, mechanisms of actions and research issues. Environ Health Perspect 1999; 107: 593- 97.

[32] Hei TK. Research reports: Arsenic and cancer. J Coll Phys Surg Col Uni 1999; 19(2): 1-3.

[33] Abrefah RG, Adotey DK, Mensimah E, Ampomah-Amoako E, Sogbadji RBM, Opata NS. Biomonitoring of occupational exposure to total arsenic and total mercury in urine of goldmine workers in southwestern Ghana. Environm Res Eng Manage 2011; 56(2): 43-48.

[34] World Health Organisation (WHO), Environmental Health Criteria (18), Arsenic, Geneva, Switzerland 1981.

[35] National Research Council (NRC), Arsenic in drinking water, Washington, DC, USA, National Academy Press 1999.

[36] Sela H, Karpas Z, Zoriy M, Pickhardt C, Becker JS. Biomonitoring of hair samples by laser ablation inductively coupled plasma mass spectrometry (LA-ICP-MS). Int J Mass Spectrom 2007; 261: 199.

[37] Rogers CE, Tomita AV, Trowbridge PR, Gone JK, Chen J, Zeeb P, Hemond HF, Thillly WG, Olmez I, Durant JL. Hair analysis does not support hypothesized arsenic and chromium exposure from drinking water in Woburn, Massachusetts. Environ Health Perspect 1997; 105: 1090-1097.

[38] Koons RD, Peters CA. Axial distribution of arsenic in individual human hairs by solid sampling graphite furnace AAS. J Anal Toxicol 1994; 18: 36-40.

[39] Arsenic in Drinking Water. Subcommitee on Arsenic in Drinking Water Committee on Toxicology. Board on Environmental Studies and Toxicology Commission on Life Sciences. National Research Council. National Academy Press. Washington, D.C., USA 2001. 
[40] WHO (2000). Arsenic. In: Air quality guidelines for Europe, 2nd ed. Copenhagen, World Health Organization Regional Office for Europe, pp. 125-128, Access Date: June 15, 2017 [http://www.euro.who.int/_data/assets/pdf_file/0005/74732/E71922.pdf].

[41] IARC (1987). Summaries \& evaluations: Arsenic and arsenic compounds (Group 1). Lyon, International Agency for Research on Cancer, p. 100 (IARC Monographs on the Evaluation of Carcinogenic Risks to Humans, Supplement 7; Access Date: June 15, [http://www.inchem.org/documents/iarc/suppl7/arsenic.html]

[42] Buchet JP, Lauwerys R, Roels H. Urinary excretion of inorganic arsenic and its metabolites after repeated ingestion of sodium metaarsenite by volunteers. Int Arch Occup Environ Health 1981; 48: 111-118.

[43] Garcia F, Ortega A, Domingo JL, Corbella J. Accumulation of metals in autopsy tissues of subjects living in Tarragona county, Spain. J Environ Sci Health Part A 2001; 36(9): 1767-1786.

[44] Mandal BK, Ogra Y, Suzuki KT. Speciation of arsenic in human nail and hair from arsenic affected area by HPLCinductively coupled argon plasma mass spectrometry. Toxicol Appl Pharmacol. 2003; 189(2): 73-83.

[45] Tsuji JS, Van Kerkhove MD, Kaetzel RS, Scrafford CG, Mink PJ, Barraj LM, Crecelius EA, Goodman M. Evaluation of exposure to arsenic in residential soil. Environ Health Perspect. 2005; 113(12):1735-1740.

[46] Hewitt DJ, Millner GC, Nye AC, Simmons HF. Investigation of arsenic exposure from soil at a Superfund site. Environ Res. 1995; 68(2): 73-81.

[47] Raie RM. Regional variation in As, $\mathrm{Cu}, \mathrm{Hg}$, and Se and interaction between them. Ecotoxicol Environ Saf. 1996; 35(3): 248-252.

[48] Gebel T, Birkenkamp P, Luthin S, Dunkelberg H. Arsenic (III), but not antimony(III), induces DNA-protein crosslinks. Anticancer Res. 1998; 18:4253-4258.

[49] Kraus T, Quidenus G, Schaller KH. Normal values for arsenic and selenium concentrations in human lung tissue. Arch Environ Contam Toxicol. 2000; 38: 384-389.

[50] Lin LH, Huang YL, Wang MY. Arsenic species in drinking water, hair, finger nails, and urine of patients with blackfoot disease. J Toxicol Environ Health. 1997; 53: 85-93.

[51] Dang HS, Jaiswal DD, Somasundaram S. Distribution of arsenic in human tissues and milk. Sci. Total Environ. 1983; 29: 171-175.

[52] Srivastava AK, Hasan SK, Srivastava RC. Arsenicism in India: dermal lesions and hair levels. Environ Int 2002; 27: 597-604.

[53] Yang L, Wang W, Hou S, Peterson PJ, William WP. Effects of selenium supplementation on arsenism: an intervention trial in inner mongolia. Environ Geochem Health 2002; 24: 359-374.

[54] Hinwood AL, Sim MR, Jolley D, de Klerk N, Bastone EB, Gerostamumoulos J, Drummer OF. Hair and toenail arsenic concentrations of residents living in areas with high environmental arsenic concentrations. Environ Health Persp. 2003;12:187-193.

[55] Zhuang GS, Wang YS, Tan MG, Zhi M, Pan WQ, Cheng YD. Preliminary study of the distribution of the toxic elements As, Cd, and $\mathrm{Hg}$ in human hair and tissues by RNAA. Biol Trace Elem Res. 1989; 26-27:729-36.

[56] Yang LS, Hou SF, Tan JA, Wenyu WWZ, Ribang L. Chinese hair As content background and its regional distribution. Acta Geogr Sin. 1996; 51(2): 135-41.

[57] Tang MX, Cross P, Andrews H. Incidence of AD in African- Americans, Caribbean Hispanics, and Caucasians in northern Manhattan. Neurology. 2001; 56: 49-56.

[58] Xu YY, Wang Y, Li X, He M, Xue P, Fu JQ, Wang HH, Sun GF. Variations in arsenic methylation capacity and oxidative DNA lesions over a 2-year period in a high arsenic-exposed population. Int Arch Occup Environ Health. 2009; 82: 251-258.

[59] Jin YL, Liang CK, He GL, Cao J. Study on distribution of endemic arsenism in China. J Hyg Res. 2003; 32: 519-540.

[60] Hsueh YM, Wu WL, Huang YL, Chiou HY, Tseng CH, Chen CJ. Low serum carotene level and increase risk of ischemic heart disease related to long-term arsenic exposure. Atherosclerosis. 1998; 141: 249-257.

[61] Afridi HI, Kazi TG, Kazi AG, Shah F, Wadhwa SK, Kolachi NF, Shah AQ, Baig JA, Kazi N. Levels of arsenic, cadmium, lead, manganese and zinc in biological samples of paralysed steel mill workers with related to controls. Biol Trace Elem Res. 2011; 144: 164-182. 